\title{
Antiproliferative Activity of Kenyan Trametes versicolor Aqueous Extract on Selected Cancer and Normal Cell Lines
}

\author{
Chengo $\mathrm{JK}^{1 *}$, Adipo $\mathrm{N}^{2}$, Kiboi DM¹, Lusweti $\mathrm{JM}^{3}$, Mwatha $\mathrm{J}^{3}$, Mwitari PG ${ }^{2}$, Ngule $\mathrm{CM}^{2}$ and $\mathrm{Njagi} \mathrm{SM}^{2}$ \\ ${ }^{1}$ Department of Biochemistry, Jomo Kenyatta University of Agriculture and Technology, Nairobi, Kenya \\ ${ }^{2}$ Centre for Traditional Medicine and Drug Research, KEMRI, Kenya \\ ${ }^{3}$ Centre for Biotechnology and Research Diseases, KEMRI, Kenya
}

\begin{abstract}
Cancer is a major public health burden in both developed and developing countries. The current conventional cancer therapies like chemotherapy are expensive and inaccessible to many cancer patients. Commercial and wild edible mushrooms are becoming more important for their nutritional value and are becoming an alternative source of immune modulation and anticancer agents. Although Previous studies with Trametes versicolor mushroom from various parts of the world have demonstrated antiproliferative activity on various cancer cell lines, the antiproliferative activity of the recently identified Kenyan $T$. versicolor mushroom have not been studied. This study examined the in vitro antiproliferative activity of an aqueous extract of the Kenyan $T$. versicolor mushroom on breast cancer (4T1), prostate cancer (DU145), hepatocellular carcinoma (HCC), rat normal intestinal epithelial cells (IEC-6) and African green monkey normal kidney (vero) cell lines using MTT assay. The results demonstrated that the $T$. versicolor extract at $1.37 \mu \mathrm{g} / \mathrm{ml}$ to $1000 \mu \mathrm{g} / \mathrm{ml}$ dose-dependently inhibited the proliferation of DU145 and 4T1cell lines with $\mathrm{IC}_{50}$ values: DU145 $(71.2 \mu \mathrm{g} / \mathrm{ml})$ and 4T1 $(188.5 \mu \mathrm{g} / \mathrm{ml})$. The extract however did not exert any significant antiproliferative effect on HCC, IEC-6 and Vero cell lines $\left(\mathrm{IC}_{50}>1000 \mu \mathrm{g} / \mathrm{ml}\right)$ when compared with a chemotherapeutic anticancer drug, tamoxifen $(p<0.05)$, confirming the tumor-selective cytotoxicity on cancer cell lines and its safety on normal cell lines. In all cell lines, the extract showed a significant difference in inhibition of cell proliferation between the untreated cells and the highest concentration $(1000 \mu \mathrm{g} / \mathrm{ml})(p<0.05)$. Presence of phytochemicals such as saponins, tannins, steroids, terpenoids and flavonoids in the $T$. vesicolor extract used might be the probable reason for its antiproliferative activity.
\end{abstract}

Keywords: Trametes versicolor; Antiproliferation; Cancer; Cell line; Inhibition; Viability

\section{Introduction}

Cancer is a disease characterized by irregular proliferation of cells with a manifestation of malfunctions in immunity as malignant cells manage to escape recognition and elimination by the immune system [1]. Cancer cells display a broad spectrum of genetic alterations that may include gene rearrangements, point mutations, and gene amplifications, leading to disturbances in molecular pathways regulating cell growth, survival and metastasis [2]. Anyone can develop cancer and the risk of being diagnosed with cancer increases with age. About $77 \%$ of all cancers are diagnosed in people 55 years of age and older [3].

Chemotherapy, surgery, immunotherapy and radiotherapy remain to be the most effective conventional methods in cancer treatment. However, they are expensive and can cause serious side effects as these do not often show adequate differential effect between tumor and normal cells [2], hence the need for affordable but effective ways of cancer management.

More than $50 \%$ of all modern drugs in clinical use are of natural product origins, many of which have antiproliferative ability [4]. According to World Health Organization estimates, more than $80 \%$ of people in developing countries depend on traditional medicine for their primary health needs including cancer management [5]. A survey done in the year 2008 showed that more than $60 \%$ of cancer patients use herbs as therapy [6]. An attempt has been made to explore the potential of newly discovered anticancer compounds from medicinal mushrooms as a lead for anticancer drug development [5]. Mushrooms have key medicinal uses including anticancer activity [7], immunomodulating effects and antiproliferative activity [8]. Trametes versicolor mushroom, also called 'Turkey tail' has been widely studied and its antiproliferative activity on different cancer cell lines has been well documented [9-11].

In Japan, polysaccharide-Krestin (PSK) extracted from T. versicolor mushroom is prescribed to cancer patients routinely, both during and after radiation and chemotherapy [12-15]. In the United States of America, whole, freeze-dried T. versicolor is commonly prescribed to breast cancer patients [16].

In some studies done in China to test for the antiproliferative activity of $T$. versicolor extract, results showed that the extract could inhibit the proliferation of four breast cancer cells (T-47D, Bcap37, ZR7530, MCF-7), B-cell lymphoma (Raji), human promyelocytic leukemia (HL-60, NB-4) and liver cancer cell line (7703) [17,18]. However, the extracts of T. versicolor mushroom have been reported to be non-toxic to several normal cells [19-21] and in cancer patients on clinical trials [22-24]. Differences in the ecological zones where mushroom exist and the influence of some environmental factors may account for the overall composition and activity of compounds present in mushrooms $[25,26]$. This study therefore investigated the antiproliferative potential

*Corresponding author: John Kahindi Chengo, Department of Biochemistry, Jomo Kenyatta University of Agriculture and Technology, P.O Box 6200-00200 Nairobi, Kenya, Tel: +254721848956; E- mail: johnchengo@yahoo.com

Received October 13, 2016; Accepted November 25, 2016; Published November 28 2016

Citation: Chengo JK, Adipo N, Kiboi DM, Lusweti JM, Mwatha J, et al. (2016) Antiproliferative Activity of Kenyan Trametes versicolor Aqueous Extract on Selected Cancer and Normal Cell Lines. J Cancer Sci Ther 8: 276-281. doi: 10.4172/1948-5956.1000427

Copyright: (c 2016 Chengo JK, et al. This is an open-access article distributed under the terms of the Creative Commons Attribution License, which permits unrestricted use, distribution, and reproduction in any medium, provided the original author and source are credited. 
of the recently identified Kenyan T. versicolor mushroom against breast cancer (4T1), prostate cancer (DU145), hepatocellular carcinoma (HCC), rat normal intestinal epithelial cells (IEC-6) and African green monkey normal kidney (vero) cell lines. We report significant anti proliferative activity of T. versicolor aqueous extract on DU145 and 4T1 cell lines, with insignificant antiproliferative activity on HCC, IEC-6 and vero cells.

\section{Material and Methods}

\section{Reagents}

The cells used were Breast cancer cell line (4T1), hepatocellular carcinoma cell line (HCC), human prostate cancer cell line (DU145), African green monkey kidney cell line (Vero) and rat normal intestinal epithelial cell line (IEC-6) which were obtained from the center for traditional medicine and drug research (CTMDR) at Kenya medical research institute (KEMRI). The RPMI-1640 medium and fetal calf serum were purchased from Gibco Laboratories (Grand Island, NY, USA). The MTT (3-(4,5-dimethylthiazolyl)-2, 5-diphenyl-tetrazolium bromide), dimethyl sulfoxide (DMSO) and other chemicals used were purchased from Sigma Chemical Co. (St. Louis, MO, USA).

\section{Collection and preparation of mushrooms}

Trametes versicolor were botanically identified by a botanist and collected from Arabuko Sokoke forest at the Kenyan coast and evaluated at KEMRI laboratories. Voucher specimens were deposited at the University of Nairobi herbarium. The mushroom T. versicolor were cut into small pieces and dried at room temperature. The dried materials were ground in a food grinder (mincer) to a fine powder, packed in bags, and stored at room temperature until use.

\section{Aqueous extraction of the mushrooms}

Aqueous extraction of T. versicolor was done according to Piero [27] and Kigondu [28] with modifications. Briefly, $100 \mathrm{~g}$ of the previously prepared powder of the mushroom $T$. versicolor was measured using an electrical beam balance and put into a $500 \mathrm{ml}$ conical flask. Double distilled water was added until the sample was completely submerged. The mixture was then transferred into a water bath at $80^{\circ} \mathrm{C}$ for 3 hours and cooled to room temperature. The mixture was then filtered using Whatman no. 1 filter paper into a clean sterile $1000 \mathrm{ml}$ conical flask and the solvent removed using a freeze drying machine. The resulting extract was weighed and stored in an airtight bottle at $-20^{\circ} \mathrm{C}$ until use.

\section{Antiproliferative activity}

The antiproliferative activity of the mushroom extract was evaluated using MTT (3-(4,5-dimethylthiazolyl)-2, 5-diphenyltetrazolium bromide) assay (Sigma, USA). The assay detects the reduction of MTT by mitochondrial dehydrogenase to blue formazan product, which reflects the normal function of mitochondria and cell viability [18]. Formazan, which is an insoluble yellow colored product can be measured spectrophotometrically $[29,30]$ and the activity of mitochondrial dehydrogenase enzyme to produce formazan is directly and inversely proportional to the level of cell viability and inhibition respectively [31].

Cells were maintained as monolayer cultures in RPMI-1640 medium supplemented with $10 \%$ fetal bovine serum and incubated at $37^{\circ} \mathrm{C}$ in a humidified incubator at $5 \% \mathrm{CO}_{2}$. Five types of cells were seeded in 96-well plates with the final volume $100 \mu$ l containing 24,000 cells per well, with the cell density determined using trypan blue exclusion assay. The fourth, eighth and twelfth columns of the 96 well plates contained $100 \mu \mathrm{l}$ RPMI-1640 with no cells as they were treated as blanks for each cell line. The plates were incubated at $37^{\circ} \mathrm{C}$ for 48 hours. The T. versicolor extract in PBS was proportionally diluted with RPMI1640 , and $50 \mu \mathrm{l}$ of each solution was added to triplicate wells in the concentrations: $1000 \mu \mathrm{g} / \mathrm{ml}, 333.33 \mu \mathrm{g} / \mathrm{ml}, 111.11 \mu \mathrm{g} / \mathrm{ml}, 37.04 \mu \mathrm{g} / \mathrm{ml}$, $12.35 \mu \mathrm{g} / \mathrm{ml}, 4.12 \mu \mathrm{g} / \mathrm{ml}$ and $1.37 \mu \mathrm{g} / \mathrm{ml}$ with the last raw of the 96 well plate left untreated to serve as a cell control. After 48 hours incubation in $5 \% \mathrm{CO}_{2}$ humidified environment at $37^{\circ} \mathrm{C}$, a volume of $10 \mu \mathrm{l}$ of PBS containing $5 \mathrm{mg} / \mathrm{ml}$ MTT was then added into each well including all the controls and plates further incubated for 3 hours. The medium was removed and $100 \mu \mathrm{l}$ DMSO added into each well. After the plates were shaken mildly, the absorbance of the samples was measured at $560 \mathrm{~nm}$ with a Multiskan Spectrum Microplate Spectrophotometer. Determination of cell proliferation was achieved using the formular developed by Patel et al. [30] and Awasare et al. [32], as follows;

$$
\begin{aligned}
& \text { Proliferation rate }=\frac{A t-A b}{A c-A b} \\
& \text { Percentage viability }=\frac{A t-A b}{A c-A b} \times 100 \\
& \text { Percentage inhibition }=100-\left(\frac{A t-A b}{A c-A b} \times 100\right)
\end{aligned}
$$

Where At=Absorbance value of test compound

$\mathrm{Ab}=$ Absorbance value of Blank

$\mathrm{Ac}=\mathrm{Absorbance}$ value of negative control (untreated Cells)

\section{Statistical analysis}

Results were expressed as the mean \pm standard error of the mean (SEM) for all the different concentrations of the mushroom extracts. Statistical differences between the concentration means were assessed by One-way ANOVA and the means subjected to Tukey's post-hoc test for pairwise comparison with values of $\mathrm{p}<0.05$ considered as statistically significant. Generated dose response curves were used to determine $\mathrm{IC}_{50}$ values. Student's unpaired t-test was then used to compare the $\mathrm{IC}_{50}$ values of T. versicolor to that of Tamoxifen. Data analysis was done using Excel spread sheets and Minitab statistical software version 17.0.

\section{Qualitative phytochemical analysis of Trametes versicolor extract}

A qualitative phytochemical analysis of the crude mushroom extract was performed using standard protocols described by Odebiyi and Sofowora [33].

Test for alkaloids: Weight of $0.5 \mathrm{~g}$ of the extract was stirred with 5 $\mathrm{ml}$ of $1 \%$ aqueous hydrochloric acid for two minutes on a steam water bath. The mixture was filtered and few drops of Dragendorff's reagent was added. The sample was then observed for color change or turbidity to draw inference.

Test for saponins: The persistent frothing test for saponin described by Odebiyi and Sofowora [33] was used. A volume of $30 \mathrm{ml}$ distilled water was added to $1 \mathrm{~g}$ of the mushroom extract. The mixture was vigorously shaken and heated on a steam water bath. The sample was observed for the formation of stable froth to draw inference.

Test for phlobatannins: Weight of $0.2 \mathrm{~g}$ of the mushroom extract was dissolved in $10 \mathrm{ml}$ of distilled water and filtered. The filtrate was then 
boiled with $2 \%$ hydrochloric acid solution and observed for deposition of red precipitate which indicates the presence of phlobatannin.

Test for tannins: The method of Trease and Evans [34] was adopted where $0.5 \mathrm{~g}$ of the mushroom extract was dissolved in $5 \mathrm{ml}$ of distilled water, then, boiled gently and cooled. One $\mathrm{ml}$ of the solution was dispensed in a test tube and 3 drops of $0.1 \%$ ferric chloride solution were added and observed for brownish green or blue black colouration which indicates the presence of tannins.

Test for terpenoids: The Salkowski test was used. A weight of $5 \mathrm{~g}$ of the extract was dissolved in $5 \mathrm{ml}$ distilled water. The mixture was then added in $2 \mathrm{ml}$ of chloroform, and $3 \mathrm{ml}$ concentrated sulphuric acid was carefully added to form a layer. The solution was then observed for reddish brown colouration which confirms the presence of terpenoids.

Test for steroids: A volume of $2 \mathrm{ml}$ acetic anhydride was added to $0.5 \mathrm{~g}$ of the mushroom extract and filtered. Two $\mathrm{ml}$ of Sulphuric acid was added to the filtrate and observed for colour change from violet to blue or green, which indicates the presence of steroids.

Test for flavonoids: A volume of $5 \mathrm{ml}$ diluted ammonia solution was added to $0.5 \mathrm{~g}$ of the mushroom extract dissolved in $5 \mathrm{ml}$ distilled water. This was then followed by the addition of a concentrated sulphuric acid. The solution was observed for yellow colouration that disappears on standing to confirm the presence of flavonoids.

Test for anthraquinones (Borntrager's test): A weight of $0.5 \mathrm{~g}$ of the mushroom extract was shaken with $10 \mathrm{ml}$ of benzene, filtered and $5 \mathrm{ml}$ of $10 \%$ ammonia solution added to the filtrate. The mixture was then shaken and observed for the presence of pink red or violet colour in the ammonia layer which indicates the presence of free anthraquinones.

\begin{tabular}{|c|c|}
\hline Phytochemical extract & T. versicolor aqueous \\
\hline Saponin & + \\
\hline Tannin & + \\
\hline Steriod & + \\
\hline Alkaloid & + \\
\hline Terpenoid & + \\
\hline Flavonoids & - \\
\hline Anthraquinone & - \\
\hline Phlobatannin
\end{tabular}

The $(+)$ sign denotes presence of phytochemicals while (-) sign denotes absence of phytochemicals.

Table 1: Qualitative phytochemical screening of $T$. versicolor aqueous extract.

\begin{tabular}{|c|c|c|c|c|c|c|c|c|c|c|}
\hline \multirow{2}{*}{$\begin{array}{l}\text { Concentra- } \\
\text { tion }(\mu \mathrm{g} / \mathrm{ml})\end{array}$} & \multicolumn{5}{|c|}{$\%$ Viability } & \multicolumn{5}{|c|}{$\%$ Inhibition } \\
\hline & $4 T 1$ & DU145 & $\mathrm{HCC}$ & IEC-6 & Vero & $4 T 1$ & DU145 & $H C C$ & IEC-6 & Vero \\
\hline $\begin{array}{l}\text { Untreated } \\
\text { cells }\end{array}$ & 100 & 100 & 100 & 100 & 100 & 0 & 0 & 0 & 0 & 0 \\
\hline 1.37 & 96 & 84 & 95 & 92 & 97 & 4 & 16 & 5 & 8 & 3 \\
\hline 4.12 & 94 & 74 & 90 & 89 & 94 & 6 & 26 & 10 & 11 & 6 \\
\hline 12.35 & 83 & 68 & 89 & 86 & 92 & 17 & 32 & 11 & 14 & 8 \\
\hline 37.04 & 70 & 52 & 85 & 70 & 88 & 30 & 48 & 15 & 30 & 12 \\
\hline 111.11 & 60 & 41 & 81 & 65 & 86 & 40 & 59 & 19 & 35 & 14 \\
\hline 333.33 & 31 & 35 & 65 & 60 & 74 & 69 & 65 & 35 & 40 & 26 \\
\hline 1000.00 & 22 & 9 & 59 & 56 & 57 & 78 & 91 & 41 & 44 & 43 \\
\hline
\end{tabular}

Results are expressed as the Mean of three independent experiments of three wells each which were calculated from the OD values obtained from a spectrophotometer.

Table 2: Percentage viability and percentage inhibition for effect of aqueous extract of $T$. versicolor mushroom on 4T1, DU145, HCC, IEC-6 and vero cell lines.

\begin{tabular}{|c|c|c|}
\hline Cell line & Drug & IC $_{50}(\boldsymbol{\mu g} / \mathbf{m l}) \pm$ SEM \\
\hline $4 T 1$ & 1 & $188.53 \pm 4.81^{\mathrm{a}}$ \\
\hline $4 T 1$ & 2 & $163.33 \pm 8.82^{\mathrm{a}}$ \\
\hline DU145 & 1 & $71.16 \pm 3.48^{\mathrm{b}}$ \\
\hline DU145 & 2 & $63.33 \pm 3.48^{\mathrm{bc}}$ \\
\hline IEC-6 & 2 & $42.20 \pm 5.64^{\text {cd }}$ \\
\hline HCC & 2 & $41.37 \pm 5.49^{\text {cd }}$ \\
\hline Vero & 2 & $36.46 \pm 2.69^{\mathrm{d}}$ \\
\hline IEC-6 & 1 & - \\
\hline HCC & 1 & - \\
\hline Vero & 1 & - \\
\hline
\end{tabular}

1= $T$. versicolor, 2=Tamoxifen (Reference drug).

Results are expressed as the Mean \pm SEM of three independent experiments of three wells each. Values that do not share a superscript are significantly different $(P>0.05)$. i.e: $I C_{50}$ values on $4 \mathrm{TI}$ cells treated with drug 1 and drug 2 are statistically not different. Drug 1 ( $T$. versicolor) did not produce $\mathrm{IC}_{50}$ values on IEC-6, HCC and vero cell lines $\left(I_{50}>1000 \mu \mathrm{g} / \mathrm{ml}\right)$.

Table 3: Statistical comparison on the $\mathrm{IC}_{50}$ values between $T$. versicolor extract and Tamoxifen (reference drug) on the 5 cell lines.

\section{Results}

\section{Qualitative phytochemical analysis of $T$. versicolor aqueous extract}

Results from the phytochemical analysis of the aqueous extracts of the Kenyan T. versicolor mushroom revealed the presence of saponins, tannins, steroids, terpenoids and flavonoids while anthraquinones, alkaloids and phlobatannins were absent (Table 1).

\section{Antiproliferative potential of $T$. versicolor aqueous extract}

This study evaluated the antiproliferative potential of $T$. versicolor aqueous extracts on five cell lines namely 4T1, DU145, HCC, IEC-6 and Vero cell lines. The T. versicolor aqueous extract at $1.37 \mu \mathrm{g} / \mathrm{ml}$ to 1000 $\mu \mathrm{g} / \mathrm{ml}$ exhibited dose-dependent inhibitory effects on the proliferation of DU145 and 4T1 cells with more than $90 \%$ and $70 \%$ suppression respectively at the highest concentration (Table 2). However, the extract induced a low level of suppression on the proliferation of HCC, normal IEC-6 and normal Vero cells showing values of $41.19 \%$, $43.85 \%$ and $42.64 \%$ respectively at the highest concentration (Table 2). Table 3 shows the concentrations producing 50\% growth inhibition $\left(\mathrm{IC}_{50}\right)$ of the T. versicolor extract on the five cell lines of which DU145 proliferation was most potently suppressed with the lowest $\mathrm{IC}_{50}$ value $(71.16 \mu \mathrm{g} / \mathrm{ml})$ followed by $4 \mathrm{~T} 1$ cells $\left(\mathrm{IC}_{50}=188.53 \mu \mathrm{g} / \mathrm{ml}\right)$ after incubation with the $T$. versicolor extract. The T. versicolor extract did not record any $\mathrm{IC}_{50}$ values against $\mathrm{HCC}$, vero and IEC- 6 cell lines even at the highest concentration $(1000 \mu \mathrm{g} / \mathrm{ml})$. The $\mathrm{IC}_{50}$ values of $T$. versicolor against all cell lines used were statistically compared to those of the reference drug (Tamoxifen) where results revealed that there was no statistical difference between the $\mathrm{IC}_{50}$ values of $T$. versicolor extract and Tamoxifen against DU145 and $4 \mathrm{~T} 1$ cells (Table 3 ).

All cell lines treated with the aqueous extract of T. versicolor had a general reduction in their viability with the extract showing a general increase in the percentage inhibition on all cell lines used (Table 2). The mushroom extract demonstrated a dose dependent inhibition of cell proliferation in all cell lines used. As the concentration of the mushroom extract increased from $1.37 \mu \mathrm{g} / \mathrm{ml}$ to $1000 \mu \mathrm{g} / \mathrm{ml}$, the percentage viability decreased, showing the lowest viability at 1000 $\mu \mathrm{g} / \mathrm{ml}$ and the highest in untreated cells with HCC and DU145 cell lines showing the highest and lowest viability respectively (Table 2). A general reduction on the proliferation rate against all cell lines used was recorded. As the concentration of the mushroom extract increased, 


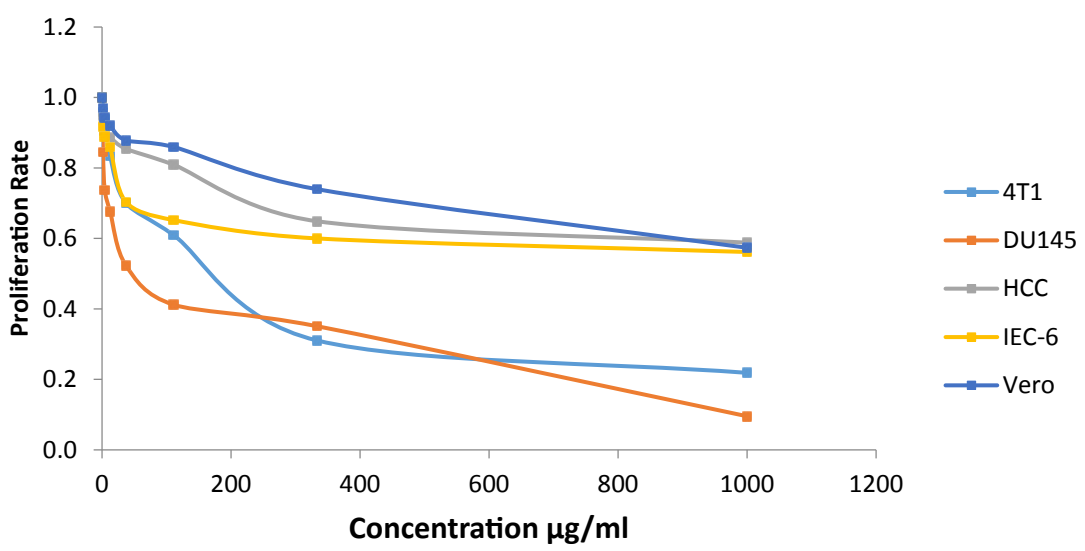

Figure 1: Dose response curve showing the effect of aqueous extract of $T$. versicolor on the proliferation rate on 4T1, DU145, HCC, IEC-6 and Vero cell lines.

\begin{tabular}{|c|c|c|c|c|c|}
\hline \multirow{2}{*}{$\begin{array}{c}\text { Concentration }(\mu \mathrm{g} / \mathrm{ml}) \\
\text { T. versicolor }\end{array}$} & \multicolumn{5}{|c|}{ Proliferation rate Cell line } \\
\hline & 4T1 & DU145 & $\mathrm{HCC}$ & IEC-6 & Vero \\
\hline Untreated cells & $1.00 \pm 0.02^{\mathrm{a}}$ & $1.00 \pm 0.01^{a}$ & $1.00 \pm 0.01^{\mathrm{a}}$ & $1.00 \pm 0.01^{a}$ & $1.00 \pm 0.01^{a}$ \\
\hline 1.37 & $0.96 \pm 0.01^{\mathrm{a}}$ & $0.84 \pm 0.00^{\mathrm{ab}}$ & $0.95 \pm 0.00^{\mathrm{ab}}$ & $0.92 \pm 0.01^{b}$ & $0.97 \pm 0.01^{\mathrm{ab}}$ \\
\hline 4.12 & $0.94 \pm 0.02^{\mathrm{a}}$ & $0.74 \pm 0.04^{\text {bc }}$ & $0.90 \pm 0.01^{\mathrm{abc}}$ & $0.89 \pm 0.00^{b}$ & $0.94 \pm 0.01^{\mathrm{abc}}$ \\
\hline 12.35 & $0.83 \pm 0.02^{\mathrm{ab}}$ & $0.68 \pm 0.01^{\mathrm{cd}}$ & $0.89 \pm 0.02^{\mathrm{bc}}$ & $0.86 \pm 0.00^{b}$ & $0.92 \pm 0.01^{\text {bcd }}$ \\
\hline 37.04 & $0.70 \pm 0.01^{\mathrm{bc}}$ & $0.52 \pm 0.02^{\mathrm{de}}$ & $0.85 \pm 0.02^{\mathrm{bc}}$ & $0.70 \pm 0.01^{c}$ & $0.88 \pm 0.03^{\text {cd }}$ \\
\hline 111.11 & $0.61 \pm 0.04^{c}$ & $0.41 \pm 0.05^{\text {ef }}$ & $0.81 \pm 0.01^{\circ}$ & $0.65 \pm 0.03^{\text {cd }}$ & $0.86 \pm 0.01^{d}$ \\
\hline 333.33 & $0.31 \pm 0.01^{d}$ & $0.35 \pm 0.01^{f}$ & $0.65 \pm 0.01^{d}$ & $0.60 \pm 0.06^{d e}$ & $0.74 \pm 0.001^{\mathrm{e}}$ \\
\hline 1000.00 & $0.22 \pm 0.01^{\mathrm{e}}$ & $0.10 \pm 0.01^{9}$ & $0.59 \pm 0.02^{\mathrm{d}}$ & $0.56 \pm 0.02^{\mathrm{e}}$ & $0.57 \pm 0.02^{f}$ \\
\hline
\end{tabular}

Proliferation rates in the same cell line were compared to each other among the different concentrations of the extract. Results are expressed as the Mean \pm SEM of three independent experiments of three wells each. Values followed by the same superscript in the same cell line are not significantly different ( $P>0.05)$. In each cell line, the proliferation rate on the untreated cells is statistically different to that on the highest concentration (1000 $\mu \mathrm{g} / \mathrm{ml})$. i.e: Values followed by superscript 'a' and 'e' on $4 \mathrm{TI}$ cell line are statistically different.

Table 4: Effect of aqueous extract of T. versicolor mushroom on the proliferation rate on 4T1, DU145, HCC, IEC-6 and Vero cell lines.

the proliferation rate decreased with DU145 and $4 \mathrm{~T} 1$ cells showing the lowest proliferation rates at the highest concentration $(1000 \mu \mathrm{g} / \mathrm{ml})$. In all cell lines, the proliferation rate was lowest at $1000 \mu \mathrm{g} / \mathrm{ml}$ and the highest in untreated cells (Figure 1). There was a significant difference between proliferation rate at $1000 \mu \mathrm{g} / \mathrm{ml}$ and untreated cells in all cell lines. $(\mathrm{P}<0.05)($ Table 4$)$.

\section{Discussion}

The aqueous extract of the Kenyan T. versicolor mushroom used in this study exhibited antiproliferative activity on two cancer cells with high safety levels on normal cells. Previous studies have shown that aqueous extracts of $T$. versicolor mushroom contain natural polysaccharides which have been proven to have some anticancer activity [35]. This study evaluated the antiproliferative activity of aqueous extracts of Kenyan T. versicolor mushroom on normal and cancer cell lines namely, 4T1, DU145, HCC, IEC-6 and Vero.

The findings of this study revealed that aqueous extracts of the Kenyan T. versicolor mushroom significantly inhibited the proliferation of breast cancer cells (4T1) and human prostate cancer cells (DU145) in a dose dependent manner. Such antiproliferative activity of the $T$. versicolor extract was reflected by its high percentage inhibition (Table 2) and the relatively low $\mathrm{IC}_{50}$ values which were significantly not different to those of Tamoxifen, the reference drug used (Table 3). These findings are consistent with previous studies where ethanol-water extract of $T$. versicolor was reported to have significant inhibitory effects on human breast cancer cells, prostate cancer, human leukemia, and lymphoma cells [18]. In another study done by Cheong-Yip et al. [36], ethanolwater extract of $T$. versicolor exhibited significant antiproliferative activity on three human breast cancer cell lines (MDA-MB-231, MCF7 and T-47D) in a dose-dependent manner in vitro. Carolyn achieved similar findings et al. [37] in a clinical trial on women with breast cancer where oral preparations of $T$. versicolor administered to the subjects showed significant antiproliferative activity.

However, the aqueous extracts of T. versicolor in the present study showed a very low inhibition on the proliferation of human liver cancer cells (HCC), rat normal intestinal epithelial cells (IEC-6) and African green monkey normal kidney cells (Vero). This is shown by their high $\mathrm{IC}_{50}$ values where even the highest concentration of the mushroom extract used could not inhibit at least $50 \%$ of the cells (Table 3). In a study by Xuannwei et al. [17] on polysaccharides isolated from $T$. versicolor mushroom, the results recorded no antiproliferative activity on three human liver cancer cells (HepG2, 7721, PLC) and human normal liver cells (WRL) which corresponds with the results of this study as T. versicolor extract failed to inhibit the proliferation of human cancer liver cells (HCC). Xuannwei et al. [17] in their study recorded that the polysaccharide extract of T. versicolor showed antiproliferative activity on four breast cancer cell lines (T-47D, Bcap37, ZR7-30, MCF7) while it inhibited the proliferation of only one liver cancer cell line (7703) out of four liver cancer cell lines used. This therefore might be suggestive that $T$. versicolor extract acts on liver cancer cells selectively.

The results of this study suggest that the aqueous extract of the Kenyan T. versicolor mushroom is more actively in the inhibition of breast and prostate cancer cells than human liver cancer cells and normal cell lines. This was reflected by the low $\mathrm{IC}_{50}$ values of $71.16 \mu \mathrm{g} /$ $\mathrm{ml}$ and $188.53 \mu \mathrm{g} / \mathrm{ml}$ on prostate cancer (DU145) and breast cancer cells 
(4T1) respectively compared to liver cancer cells (HCC), rat normal intestinal epithelial cells (IEC-6) and African green monkey normal kidney cells (Vero) both of which had an $\mathrm{IC}_{50}$ value $>1000 \mu \mathrm{g} / \mathrm{ml}$ (Table 3). These results tend to agree with previous reports that T. versicolor extracts can selectively suppress the proliferation of various cancer cells with no antiproliferative activity in normal cell lines suggesting its high level of safety $[17,18,36]$. In all cell lines used in this study, there was a significant difference in the proliferation rate between the untreated cells and the highest concentration $(1000 \mu \mathrm{g} / \mathrm{ml})$ of the T. versicolor extract used (Table 4). This tendency however suggests that the extract used in this study has a dose-dependent activity on the cell lines used.

The antiproliferative activity of the T. versicolor aqueous extract used in this study can be associated with the phytochemicals found to be present in the extract. Saponis, flavonoids and Taninns, which were present in the extract have been documented from previous research to possess some anticancer activity on different cancer cell lines [38-40]. Flavonoids have demonstrated antiproliferative activity in prostate, renal, colon, non-Hodgkin's lymphoma, gastric carcinomas and neuroblastoma cancer cells [41-43]. Tannin isolated from Cuphea hyssopifolia, Phyllanthus niruri and Cistus ladanifer among other medicinal plants has been documented to have antiproliferative effects against breast, human promyelocytic leukemia HL-60, ovarian and pancreatic cancer cell lines [44-46].

The findings of this study indicates that the aqueous extract of the Kenyan T. versicolor mushroom are consistent with previous results on T. versicolor mushrooms collected from other parts of the world. However, it is probable that the phytochemicals found to be occurring in the aqueous extract of the Kenyan T. versiocolor used in this study are responsible for the antiproliferative nature of the extract. These results suggest the need for a quantitative analysis and study of the phytochemicals of the Kenyan T. versicolor mushroom. In vitro and in vivo anti-proliferative activity and evaluation of cell death mechanisms using purified active compounds extracted from the $T$. versicolor mushroom is also recommended.

\section{References}

1. Shurin MR (2012) Cancer as an immune-mediated disease. Immunotargets Ther 1: 1-6.

2. Shrikant A (2010) RNA Binding Proteins in Cancer. University of Kansas, Kansas City.

3. ACS (2011) Cancer facts and figures. American cancer society, Atlanta, USA.

4. Rosangkima G, Prasad SB (2004) Anti-tumour activity of some plants from Meghalaya and Mizoram against murine ascites Dalton's lymphoma. Indian J Exp Biol 42: 981-988.

5. Shah U, Shah R, Acharya S, Acharya N (2013) Novel anticancer agents from plant sources. Chinese Journal of Natural Medicines 6: 0016-0023.

6. Madhuri S, Pandey G (2008) Some dietary agricultural plants with anticancer properties. Plant Arch 8: 13-16.

7. Chang ST, Wasser SP (2012) The role of culinary-medicinal mushrooms on human welfare with a pyramid model for human health. Int J Med Mushrooms 14: 95-134.

8. Finimundy TC, Gambato G, Fontana R (2013) Aqueous extracts of Lentinula edodes and Pleurotus sajor-caju exhibit high antioxidant capability and promising in vitro antitumor activity. Nutr Res 33(1): 76-84.

9. Zaidman BZ, Yassin M, Mahajna J, Wasser SP (2005) Medicinal mushroom modulators of molecular targets as cancer therapeutics. Appl Microbiol Biotechnol 67: 453-468.

10. Chang R (2002) Bioactive polysaccharides from traditional Chinese medicine herbs as anticancer adjuvants. J Altern Complement Med 8: 559- 565.

11. Ebina T (2003) Activation of antitumor immunity by intratumor injection of biological preparations. Gan To Kagaku Ryoho 30: 1555-1558.
12. Morimoto, Ogawa M, Orita K (1996) Postoperative adjuvant randomised trial comparing chemoendocrine therapy, chemotherapy and immunotherapy for patients with stage II breast cancer: 5-year results from the nishinihon cooperative study group of adjuvant chemoendocrine therapy for breast cancer (ACETBC) of Japan. Eur J Cancer 32: 235-242.

13. Toi M, Hattori T, Akagi M (1992) Randomized adjuvant trial to evaluate the addition of tamoxifen and PSK to chemotherapy in patients with primary breast cancer: 5-year results from the Nishi-Nippon group of the adjuvant chemoendocrine therapy for breast cancer organization. Cancer 70: 24752483

14. Ogoshi, Satou H, Isono K (1995) Immunotherapy for esophageal cancer. A randomized trial in combination with radiotherapy and radiochemotherapy. Cooperative Study Group for Esophageal Cancer in Japan. Am J Clin Onco 18: $216-222$.

15. Kobayashi $H$, Matsunaga K, Oguchi $Y$ (1995) Antimetastatic effects of PSK (Krestin), a protein-bound polysaccharide obtained from basidiomycetes: An overview. Cancer Epidemiol Biomarkers Prev 4: 275-281.

16. Standish LJ, Alschuler LN, Ready AB (2009) Botanical medicine in integrative oncology. In: Abrams DI, Weil AT (Eds.) Integrated Oncology. Oxford University Press, New York, USA

17. Xuanwei Z, Hua J, Juan L, Kexuan T (2007) Cytotoxic activities of Coriolus versicolor (Yunzhi) extracts on human liver cancer and breast cancer cell line. Afr J Biotechnol 15: 1740-1743.

18. Lau CS, Ho CY, Kim CF, Leung KN, Fung KP, et al. (2004) Cytotoxic activities of coriolus versicolor (Yunzhi) extract on human leukemia and lymphoma cells by induction of apoptosis. Life Sci 75: 797-808.

19. Mwitari PG, Bian Y, Ayeka PA, Zhang YJ (2014) Effect of substrate dependent mushroom polysaccharide extracts on $\mathrm{IL}-7$ up regulation and cance immunotherapy and, their probable mode of action research. Int J Canc Studies Res 3(3): 41-57.

20. Dong Y, Kwan CY, Chen ZN, Yang MP (1996) Anti-tumour effects of a refined polysaccharide peptide fraction isolated from Coriolus versicolor in vitro and in vivo studies. Res Commun Mol Pathol Pharmacol 92: 140-148.

21. Dong Y, Yang MP, Kwan CY (1997) In vitro inhibition of proliferation of $\mathrm{HL}$ 60 cells by tetrandrine and Coriolous versicolor peptide derived from Chinese medicinal herbs. Life Sci 60: 135-140.

22. Kidd PM (2000) The use of mushroom glucans and proteoglycans in cancer treatment. Altern Med Rev 5: 4-27.

23. Ogoshi K, Satou H, Isono K (1995) Possible predictive markers of immunotherapy in esophageal cancer: Retrospective analysis of a randomized study. The cooperative study group for esophageal cancer in Japan. Cancer Invest 13: 363-369.

24. Go P, Chung CH (1989) Adjuvant PSK immunotherapy in patients with carcinoma of the nasopharynx. J Int Med Res 17: 141-149.

25. Samuel I, Awala, Victor O (2015) The Phytochemical and Antimicrobia Properties of the Extracts Obtained from Trametes elegans Collected from Osengere in Ibadan, Nigeria. Jordan J Biol Sci 8: 289- 299.

26. Wu B, Tian J, Bai C, Xiang M, Sun J, et al. (2013) The biogeography of fungal communities in wetland sediments along the Chang jiang River and other sites in China. ISME J 7: 1299-1309.

27. Piero NM, Joan MN, Cromwell KM, Joseph NJ, Wilson NM (2011) Hypoglycemic activity of some kenyan plants traditionally used to manage diabetes mellitus in eastern province. J Diabetes Metab 2: 155-164.

28. Kigondu EM, Rukunga GM, Gathirwa JW, Irungu BN, Mwikwabe NM (2011) Anti-plasmodial and cytotoxicity activities of some selected plants used by the Maasai community, Kenya. South Afr J Botany 77: 725-729.

29. Mosmann T (1983) Rapid colorimetric assay for cellular growth and survival: Application to proliferation and cytotoxicity assays. J Immunol Methods 65: 55-63.

30. Patel S, Gheewala N, Suthar A, Shah A (2009) In-vitro cytotoxicity activity of Solanum nigrum extract against Hela cell line and vero cell line. Int $\mathrm{J}$ Pharm Pharm Sci 1: 38-46.

31. Berridge MV, Herst PM, Tan AS (2005) Tetrazolium dyes as tools in cell biology: New insights into their cellular reduction. Biotechnol Annu Rev 11: 127-152. 
Citation: Chengo JK, Adipo N, Kiboi DM, Lusweti JM, Mwatha J, et al. (2016) Antiproliferative Activity of Kenyan Trametes versicolor Aqueous Extract on Selected Cancer and Normal Cell Lines. J Cancer Sci Ther 8: 277-282. doi: 10.4172/1948-5956.1000427

32. Awasare S, Bhujbal S, Nanda R (2012) In vitro cytotoxic activity of novel oleanane type of triterpenoid saponin from stem bark of Manilkara zapota Linn. Asian J Pharm Clin Res 5: 183-188.

33. Odebiyi OO, Sofowora EA (1978) Phytochemical screening of Nigerian medicinal plants II. Lloydia 41: 234-246.

34. Trease GE, Evans MC (2005) Pharmacognosy. (14thedtn.), Elsevier, New Delhi, India.

35. Ooi VE, Liu F (2000) Immunomodulation and anti-cancer activity of polysaccharide-protein complexes. Curr Med Chem 7: 715-729.

36. Cheong YH, Chi FK, Kwok NL, Fung KP, Tak FT, et al. (2005) Differential anti-tumor activity of Ccoriolus versicolor (Yunzhi) extract through p53- and/ or Bcl-2-dependent apoptotic pathway in human breast cancer cells. Canc Biol Ther 4(6): 638-644.

37. Torkelson CJ, Sweet E, Martzen MR, Sasagawa M, Wenner CA, et al. (2012) Phase 1 clinical trial of trametes versicolor in women with breast cancer. ISRN Oncol 2012: 251632.

38. Rivière C, Hong VN, Pieters L, Dejaegher B, Heyden YV, et al. (2009) Polyphenols isolated from antiradical extracts of Mallotus metcalfianus. Phytochemistry 70: 86-94.

39. Yildirim I, Kutlu T (2015) Anticancer agents: Saponin and Tannin. Int J Biol Chem 9(6): 332-340.

40. Mithraja MJ, Marimuthu J, Mahesh M, Paul ZM, Jeeva S (2011) Phytochemical studies on Azolla pinnata R. Br., Marsilea minuta L. and Salvinia molesta Mitch. Asian Pac J Trop Biomed 1(1): 26-29.

41. Senderowicz AM (2001) Development of cyclin-dependent kinase modulators as novel therapeutic approaches for hematological malignancies. Leukemia 15(1): 1-9.

42. Chandrappa CP, Govindappa M, Anil Kumar NV, Channabasava R, Chandrasekar N, et al. (2014) Identification and separation of quercetin from ethanol extract of carmona retusa by thin layer chromatography and high performance liquid chromatography with diode array detection. World J Pharm Pharma Sci 3(6): 2020-2029.

43. Sugantha Priya E, Selvakumar K, Bavithra S, Elumalai P, Arunkumar R, et al (2014) Anti-cancer activity of quercetin in neuroblastoma: An in vitro approach. Neurol Sci 35: 163-170.

44. Barrajon CE, Fernandez AS, Saura D, Guillen E, Fernandez GA, et al. (2010) Cistaceae aqueous extracts containing ellagitannins show antioxidant and antimicrobial capacity, and cytotoxic activity against human cancer cells. Food and Chem Toxicol 48(8): 2273-2282.

45. Jia L, Jin H, Zhou J, Chen L, Lu Y, et al. (2013) A potential anti-tumor herbal medicine, Corilagin, inhibits ovarian cancer cell growth through blocking the TGF- $ß$ signaling pathways. BMC complement Altern Med 13(1): 1-11.

46. Wang CC, Chen LG, Yang LL, Cuphiin D (2000) the macrocyclic hydrolyzable tannin induced apoptosis in HL-60 cell line. Cancer Lett 149: 77-83. 